Note

\title{
Effects of High-Pressure Carbonation on Intracellular ATP and NADH Levels and DNA Damage in Escherichia coli Cells
}

\author{
WANNAPORN KLANGPETCH ${ }^{1}$, SEIJI NOMA ${ }^{2}$, NORIYUKI IGURA ${ }^{2}$, \\ AND MITSUYA SHIMODA ${ }^{2 *}$ \\ ${ }^{1}$ Graduate School of Bioresource and Bioenvironmental Sciences, Kyushu University \\ ${ }^{2}$ Division of Bioresource and Bioenvironmental Sciences, Kyushu University, \\ 6-10-1 Hakozaki, Higashi-ku, Fukuoka 812-8581, Japan
}

Received 7 December, 2012/Accepted 19 April, 2013

\begin{abstract}
In order to understand the microbial inactivation mechanism of high-pressure carbonation (HPC), we examined the changes in the activity of the respiratory chain and DNA damage in Escherichia coli cells. HPC was performed under 1-6 MPa at $30^{\circ} \mathrm{C}$ for $1 \mathrm{~min}$. The increase in $\mathrm{CO}_{2}$ pressure decreased the number of viable cells of $E$. coli, intracellular ATP, and intracellular NADH, and increased the number of apurinic/apyrimidinic sites. These results indicate that HPC has a detrimental effect on the functioning of the respiratory chain in E. coli and induces DNA damage, which could result in the death of the bacterial cells.
\end{abstract}

Key words : Carbonation / Intracellular ATP / Intracellular NADH / Escherichia coli.

Temperature and pressure are the most important factors that affect the growth of microorganisms (Zhang et al., 2006). Currently, thermal processing is the most widely used food pasteurization method. However, an extra high temperature during the process may severely damage the organoleptic, nutritional, and physicochemical properties of heat-sensitive food products (Garcia-Gonzalez et al., 2007). As a result, owing to the rise in consumer demand for good quality food, superior sensory perception of food, high safety standards, and extended shelf life, the efforts to reduce damage to these properties should be made. Thus, many alternative non-thermal treatments such as those involving high hydrostatic pressure and pulsed electrical fields have been extensively developed during the past 20 years (Garcia-Gonzalez et al., 2007; Jeyamkondan et al., 1999; Espachs-Barroso et al., 2003; Devlieghere et al., 2004).

Hydrostatic pressure from 100 to $1000 \mathrm{MPa}$ is required to inactivate bacteria (Balasubramaniam et al., 2008). However, in the presence of $\mathrm{CO}_{2}$, it is possible to lower the pressure requirement to 5-35 MPa (Garcia-Gonzalez et al., 2007). As a result, there is a growing interest in understanding the effects of high-

*Corresponding author. Tel \& Fax: +81-92-642-3015, E-mail: mshimoda (a)agr.kyushu-u.ac.jp pressure carbonation (HPC) treatments on the inactivation of microbial activity in liquid food products such as orange juice, carrot juice, coconut water, tomato sauce, and egg mixtures (Arreola et al., 1991; Park et al., 2002; Damar and Balaban, 2005; Parton et al., 2003; Haas et al., 1989). A predictive model for HPC inactivation of microorganisms was also studied (Buzrul, 2009).

Hong and Pyun (2001) proposed that increasing the pressure would enable $\mathrm{CO}_{2}$ diffusion through cellular membranes and its accumulation within the cell. Cytoplasmic $\mathrm{CO}_{2}$ forms carbonic acid $\left(\mathrm{H}_{2} \mathrm{CO}_{3}\right)$, which dissociates into bicarbonate $\left(\mathrm{HCO}_{3}{ }^{-}\right)$, carbonate $\left(\mathrm{CO}_{3}{ }^{2-}\right)$, and hydrogen $\left(\mathrm{H}^{+}\right)$ionic species according to the following chemical equilibrium:

$$
\begin{aligned}
& \mathrm{CO}_{2}+\mathrm{H}_{2} \mathrm{O} \leftrightarrow \mathrm{H}_{2} \mathrm{CO}_{3} \leftrightarrow \mathrm{H}^{+}+\mathrm{HCO}_{3}{ }^{-} \\
& \mathrm{HCO}_{3}{ }^{-} \leftrightarrow \mathrm{H}^{+}+\mathrm{CO}_{3}{ }^{2-}
\end{aligned}
$$

The resultant rise in cytoplasmic proton concentration could lead to the simultaneous entry of the $\mathrm{CO}_{2}$ molecules into the cytoplasm. Eventually, the intracellular $\mathrm{pH}$ $\left(\mathrm{pH}_{\mathrm{in}}\right)$ of the microbial cell would decrease to the value of the extracellular $\mathrm{pH}$ due to the enhanced dissociation of carbonic acid upon pressurization (Spilimbergo et al., 2005). Under such an unfavorable acidic cytoplasmic environment, microbial growth and metabolism 
are inhibited (Wu et al., 2007).

The mechanism of the effect of low-pressure carbonation of $1 \mathrm{MPa}$ on the heat inactivation of Escherichia coli was previously investigated according to physiological damage analysis (Klangpetch et al., 2011). However, the correlation of elevating $\mathrm{CO}_{2}$ pressure and the damage in $E$. coli cell remains unclear. We hypothesized that there exists a mechanism to inactivate bacteria subjected to even relatively mild pressure carbonation (1-6 MPa). In order to understand this mechanism, E. coli was used as a model organism. Most of the earlier studies have focused on physical factors such as disruption of cells, modification of the cell membrane, and extraction of cellular components from the HPC-treated cells ( $>7 \mathrm{MPa}$ ) (Damar and Balaban, 2006). However, this study focuses on the role of physiological factors within the respiratory chain, namely, the electron transport system and $\mathrm{H}^{+}$-ATPase system, in maintaining the cytoplasmic $\mathrm{pH}$ of a bacterium. Moreover, it has been proposed that hyperactivation of the electron transport system stimulates superoxide formation, which is extremely toxic (Kohanski et al., 2007; Wei and Lee, 2002) and readily damages cellular protein and DNA (Farr and Kogoma, 1991). Therefore, we evaluated the extent of the DNA damage after HPC treatment.

E. coli NBRC 3301 was obtained from the National Institute of Technology and Evaluation (Chiba, Japan). The cells were precultured in $7 \mathrm{~mL}$ of tryptic soy broth (TSB; Difco, Detroit, MI) at $30^{\circ} \mathrm{C}$ for $12 \mathrm{~h}$, and $100 \mu \mathrm{L}$ from the resulting culture was inoculated into $7 \mathrm{~mL}$ of freshly prepared TSB. The cells in this culture were allowed to reach the late logarithmic growth phase. Cells were harvested and washed three times by centrifugation at $2,000 \times g$ at $4^{\circ} \mathrm{C}$ for 10 min in $0.9 \%$ $\mathrm{w} / \mathrm{v}$ sodium chloride solution, and the pellet was resuspended in the solution to yield a final cell concentration of $10^{8}-10^{9}$ colony forming units $(\mathrm{CFU} / \mathrm{mL})$. This cell suspension was subjected to the inactivation treatment described below.

HPC was performed by dissolving $\mathrm{CO}_{2}$ into the cell suspension at the pressure of 1-6 MPa. In the first step, the bacterial cell suspension was introduced into a $\mathrm{CO}_{2}$-dissolving vessel, using sample pump I. $\mathrm{CO}_{2}$ gas was then introduced into the vessel at a pressure of 1-6 $\mathrm{MPa}$ and dissolved, with stirring, into the cell suspension to the point of saturation at $4^{\circ} \mathrm{C}$ for $15 \mathrm{~min}$. In the second step, the cell suspension was introduced into the residence column maintained at $30^{\circ} \mathrm{C}$ in a waterbath using sample pump II. The cell suspension was withdrawn via a pressure control valve after subjecting it to 1-6 $\mathrm{MPa} \mathrm{CO}$ pressure for $1 \mathrm{~min}$ (FIG. 1). The $\mathrm{CO}_{2}$ concentration in the cell suspension was kept saturated at each treatment pressure. Saturation of $\mathrm{CO}_{2}$ in the cell

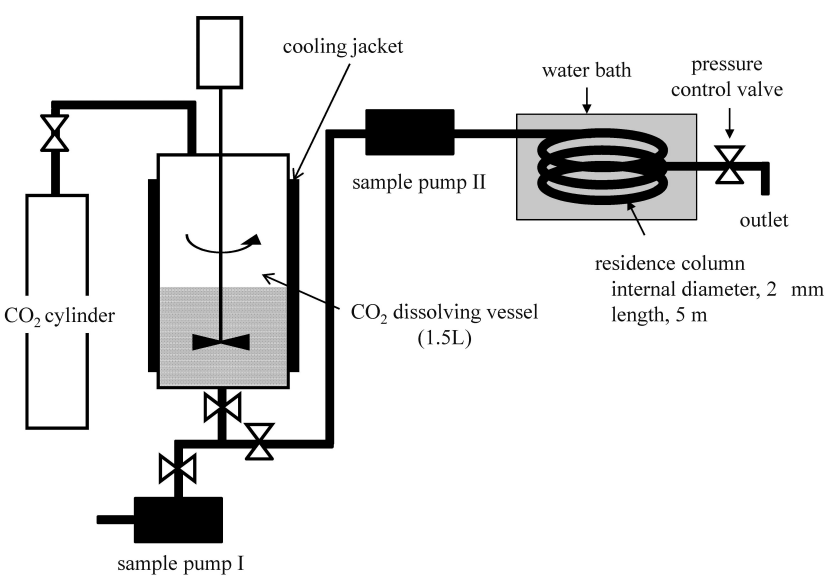

FIG. 1. Schematic diagram of the apparatus used for HPC.

suspension was determined by the method described by Shimoda et al. (2002).

Appropriate serial dilutions of each sample were prepared with a $0.9 \%$ sodium chloride solution; $0.1 \mathrm{~mL}$ of the suspension was plated onto a tryptic soy agar (TSA; Difco) plate, and the number of viable cells was counted after incubation at $30^{\circ} \mathrm{C}$ for $24 \mathrm{~h}$. The viable count $(\mathrm{CFU} / \mathrm{mL})$ was expressed as the mean \pm standard deviation for 3 independent experiments.

The amount of ATP was measured using a CheckLite ${ }^{T M} 250$ Plus kit following the manufacturer' $s$ instructions (Kikkoman, Chiba, Japan). Briefly, $0.1 \mathrm{~mL}$ of the E. coli cell suspension was mixed with $0.1 \mathrm{~mL}$ of the ATP releasing agent. After $20 \mathrm{~s}, 0.1 \mathrm{~mL}$ of luciferinluciferase reagent solution was added to the mixture, and luminescence was measured immediately with a Lumitester (C-110; Kikkoman). To eliminate extracellular ATP, a pretreatment was carried out with $1 \mathrm{~mL}$ of the sample solution that was mixed with $0.1 \mathrm{~mL}$ of the CheckLite ${ }^{\mathrm{TM}}$ ATP Eliminating Kit solution. Thirty minutes later, $0.1 \mathrm{~mL}$ of the aliquot was subjected to the bioluminescence assay described above using a CheckLite $^{\text {TM }} 250$ Plus Kit. Relative light units (RLU), representing ATP, were used to calculate the ATP concentration by plotting the RLU value on the calibration setting of $10^{-12}-10^{-7} \mathrm{M}$ of the ATP concentration.

Yellow MTT; 3- (4,5-dimethylthiazol-2-yl)-2,5-diphenyltetrazolium bromide (Nacalai Tesque, Kyoto, Japan) is reduced to purple formazan by a dehydrogenase $\left(\mathrm{NADH} \rightarrow \mathrm{NAD}^{+}\right)$in the respiratory system of living cells. Therefore, $\mathrm{NADH}_{\text {in }}$ consumption can be determined by measuring the amount of produced formazan (Mosmann, 1983).

To measure the $\mathrm{NADH}_{\text {in }}$ concentration, we used a modified version of the method described by Mosmann (1983). MTT stock solution was prepared by dissolving it in PBS buffer ( $\mathrm{pH} 7.0$ ) at a concentration of $5 \mathrm{mg} /$ $\mathrm{mL}$. Five hundred $\mu \mathrm{L}$ of this solution was added to 500 
$\mu \mathrm{L}$ of the microbial cell suspension. The mixture was incubated at $37^{\circ} \mathrm{C}$ for $4 \mathrm{~h}$. Dimethyl sulfoxide (Nacalai Tesque) was added to the mixture and mixed thoroughly to dissolve the dark blue crystals. After the mixture was left for a few minutes at room temperature to ensure complete dissolution, the absorbance was recorded at $490 \mathrm{~nm}$ using a spectrophotometer (UV-1700; Shimadzu, Kyoto, Japan). A standard curve was obtained by plotting the NADH concentrations (0.02-1.5 mM) versus the absorbances at $490 \mathrm{~nm}$.

We estimated the extent of the DNA damage by measuring the number of AP (apurinic/apyrimidinic) sites of the previously extracted E. coli DNA by using the DNA Damage Quantification Kit (Dojindo Molecular Technologies) according to the manufacturer's protocol. The number of AP sites in the genomic DNA was determined using the calibration setting of 0-40 AP sites/100,000 bp of ARP (Aldehyde Reactive Probe)DNA standard solution.

The effect of HPC on the log number of viable E. coli cells is shown in FIG. 2. Under the conditions of $\mathrm{CO}_{2}$ saturation with the pressure ranging from 1 to $6 \mathrm{MPa}$ at $30^{\circ} \mathrm{C}$ during $1 \mathrm{~min}$ of the treatment time, it appeared that the number of viable $E$. coli cells remarkably decreased with the increase in pressure. Therefore, it could be concluded that even at an appropriate growth temperature, the microbial inactivation increased with the increase in the pressure. The inactivation effect was attributed to the increasing concentration of the dissolved $\mathrm{CO}_{2}$, leading to a rise in $\mathrm{CO}_{2}$ concentration in the cell upon pressurization (Shimoda et al., 2001; Wu et al., 2007). Hence, the HPC may indeed be the preferred method for a relatively mild pressure treatment, which is effective for microbial inactivation. However, our results were inconsistent with earlier find-

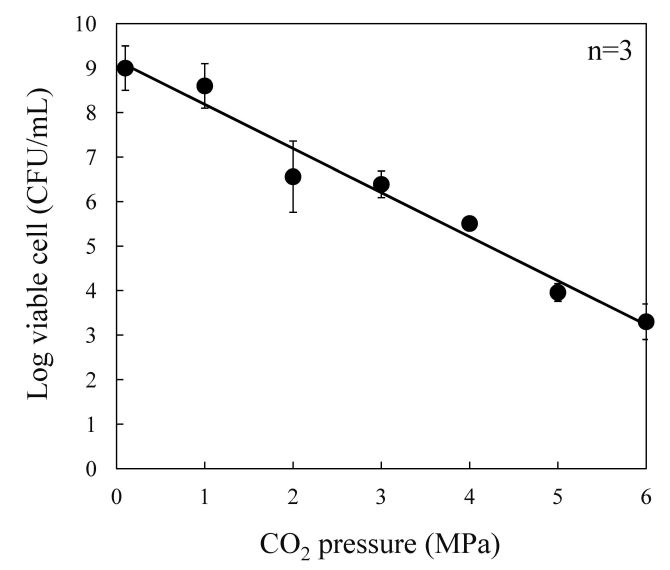

FIG. 2. Effect of HPC treatment (1-6 MPa) on the log number of viable cells of $E$. coli. HPC was carried out at $30^{\circ} \mathrm{C}$ for $1 \mathrm{~min}$. Data are expressed as the mean \pm standard deviation from 3 independent experiments.

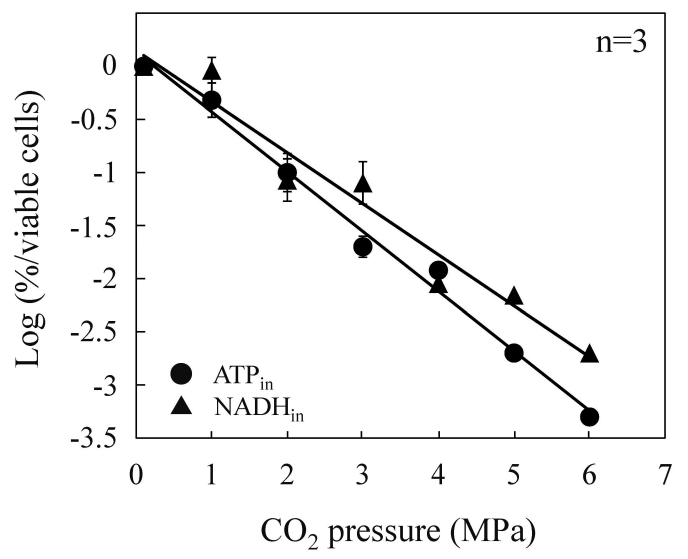

FIG. 3. Effect of HPC treatment (1-6 MPa) on $A_{T P}$ in and $\mathrm{NADH}_{\text {in }}$ in E. coli cells. HPC was carried out at $30^{\circ} \mathrm{C}$ for 1 min. Data are expressed as the percentage per viable cell and log (percentage per viable cell). Data are expressed as the mean \pm standard deviation from 3 independent experiments.

ings that have suggested that the E. coli cells are not inactivated below 4.5 MPa pressure (Oule et al., 2006); this may be attributed to the inadequate solubility of $\mathrm{CO}_{2}$ in their study.

Generally, an excess amount of protons in a cell are excreted by proton pumps like the $\mathrm{H}^{+}$-ATPase system and the electron transport system (Garcia-Gonzalez et al., 2007). Therefore, both systems are typically influenced when there is a proton excess inside the cell due to HPC. The relative amount of ATP in (calculated as percentage per viable cell) in E. coli cells after HPC treatment (1-6 MPa at $30^{\circ} \mathrm{C}$ for $1 \mathrm{~min}$ ) is shown in FIG. 3. Here, freshly prepared E. coli cells contained a high level of ATP $_{\text {in }}\left(10^{-8} \mathrm{M} /\right.$ viable cell), and this ATP concentration was set to $100 \%$. Similar to the inactivation curve illustrated in FIG. 2, log (ATP in percentage per viable cell) also decreased linearly with the increasing $\mathrm{CO}_{2}$ pressure. Therefore, the inactivation of $E$. coli cells could be at least partly due to the consumption of ATP $_{\text {in }}$ that was spent for pumping out the excess protons during HPC.

Loss of the metabolic activity in HPC-treated cells, an indicator of the activity of the electron transport system, was estimated by determining the concentration of $\mathrm{NADH}_{\text {in }}$ with tetrazolium chloride. Similar to the ATP in measurement, the freshly prepared E. coli cells contained a high level of $\mathrm{NADH}_{\text {in }}\left(1.3 \times 10^{-12} \mathrm{M} /\right.$ viable cell), and this value was set to $100 \%$. The result shows that $\log \mathrm{NADH}_{\text {in }}$ decreased linearly with the increasing $\mathrm{CO}_{2}$ pressure. Thus, it could be concluded that both $\mathrm{ATP}_{\text {in }}$ and $\mathrm{NADH}_{\text {in }}$ decreased with the increase in $\mathrm{CO}_{2}$ pressure.

FIG. 3 also suggested that HPC could enhance the oxidation of $\mathrm{NADH}$ to $\mathrm{NAD}^{+}$. This oxidation acts as a 


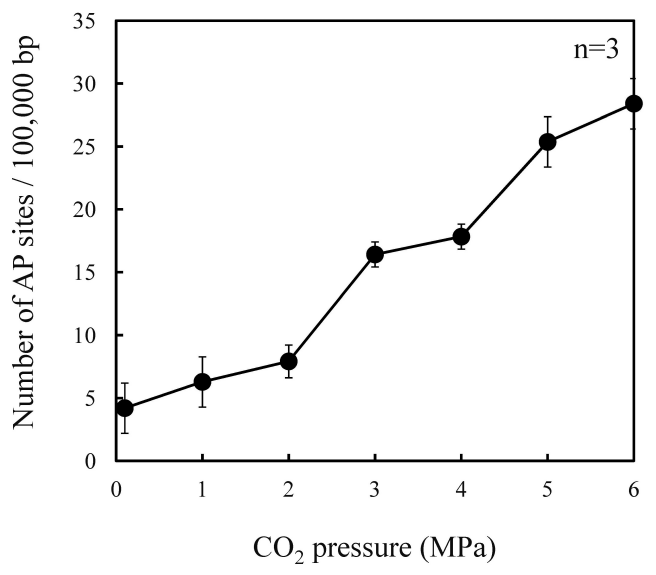

FIG. 4. Effect of HPC (1-6 MPa) on the number of AP sites/100,000 bp of E. coli DNA. HPC was carried out at $30^{\circ} \mathrm{C}$ for 1 min. Data are expressed as the mean \pm standard deviation from 3 independent experiments.

trigger for the formation of the hydroxyl radical, an extremely toxic reactive oxygen species (ROS) responsible for the oxidative damage of DNA (Farr and Kogoma, 1991). Formation of AP sites is one of the major types of DNA damage caused by ROS. These sites are usually created during the course of base excision repair of oxidized, deaminated, or alkylated bases. AP sites are repaired by AP endonucleases during the process of base excision repair (Sun et al., 2001). However, an imbalance in this DNA repair system may cause mutations as well as cell death (Boiteux and Guillet, 2004). Thus, the level of AP sites detected in cells is a good indicator of DNA damage.

As shown in FIG. 4, the AP site number increased with the increasing $\mathrm{CO}_{2}$ pressure to $28 / 100,000$ bp at 6 $\mathrm{MPa}$. The AP site number of $E$. coli upon $\mathrm{HPC}$ at $1 \mathrm{MPa}$ was approximately 6/100,000 bp. Therefore, this result suggests that HPC caused DNA damage in E. coli cells.

This study indicates that HPC at relatively mild conditions (1-6 $\mathrm{MPa}, 30^{\circ} \mathrm{C}, 1 \mathrm{~min}$ ) has a remarkable inactivating effect on $E$. coli cells. Simultaneously, we showed the dramatic decrease of ATP in, and $\mathrm{NADH}_{\text {in }}$, and the increase in the number of AP sites in the HPC-treated cells. The damage level was increased with increasing $\mathrm{CO}_{2}$ pressure. From the results of this study, we propose that carbonation treatment has a detrimental effect on the functioning of the respiratory chain in $E$. coli, i.e., the exhaustion of ATP in and $\mathrm{NADH}_{\text {in }}$ resulted from excreting the excess $\mathrm{H}^{+}$during $\mathrm{HPC}$ and also induces DNA damage, which could lead to the death of the bacterial cells (FIG. 5). As there is no thermal process required, this process might reduce the detrimental effects of antimicrobial treatments on the sensory assessment of freshness, and on the nutritional, and physical properties of food. This treatment also

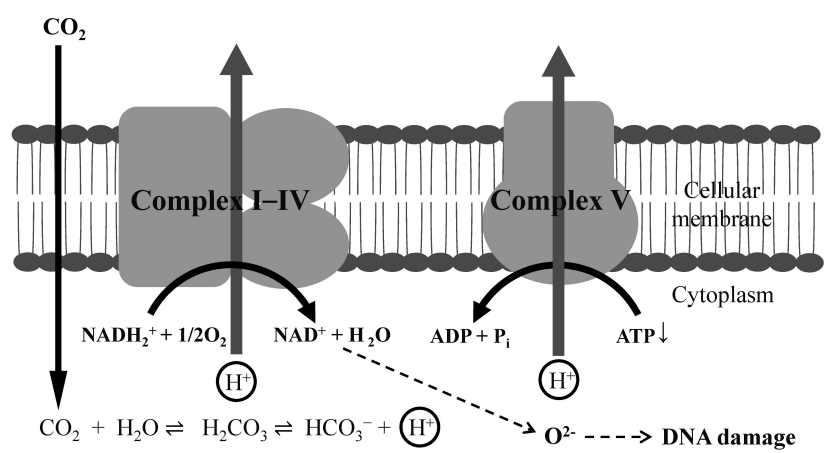

FIG. 5. Schematic diagram of a possible HPC inactivation mechanism against bacterial cells.

appears promising in various applications in the food industry.

\section{REFERENCES}

Arreola, A.G., Balaban, M.O., Marshall, M.R., Peplow, A.J., Wei, C.I., and Cornell, J.A. (1991) Supercritical carbon dioxide effects on some quality attributes of single strength orange juice. J. Food Sci., 56, 1030-1033.

Balasubramaniam, V.M., Farkas, D., and Turek, E.J. (2008) Preserving foods through high-pressure processing. Food Technol., 62, 32-38.

Boiteux, S., and Guillet, M. (2004) Abasic sites in DNA: repair and biological consequences in Saccharomyces cerevisiae. DNA Repair (Amst), 3, 1-12.

Buzrul, S. (2009) A predictive model for high-pressure carbon dioxide inactivation of microorganisms. J. Food Saf., 29, 208-223.

Damar, S., and Balaban, M.O. (2005) Cold pasteurization of coconut water with a dense-phase $\mathrm{CO}_{2}$ system. IFT Annual Meeting Book of Abstracts (pp. 1). New Orleans, La:Institute of Food Technologists.

Damar, S., and Balaban, M.O. (2006) Review of dense phase $\mathrm{CO}_{2}$ technology: Microbial and enzyme inactivation, and effects on food quality. J. Food Sci., 71, R1-R11.

Devlieghere, F., Vermeiren, L., and Debevere, J. (2004) New preservation technologies: possibilities and limitations. Int. Dairy J., 14, 273-285.

Espachs-Barroso, A., Barbosa-Canovas, G.V., and MartinBelloso, O. (2003) Microbial and enzymatic changes in fruit juice induced by high-intensity pulsed electric fields. Food Rev. Int., 19, 253-273.

Farr, S.B., and Kogoma, T. (1991) Oxidative stress responses in Escherichia coli and Salmonella typhimurium. Microbiol. Mol. Biol. Rev., 55, 561-585.

Garcia-Gonzalez, L., Geeraerd, A.H., Spilimbergo, S., Elst, K., Van Ginneken, L., Debevere, J., Van Impe, J.F., and Devlieghere, F. (2007) High pressure carbon dioxide inactivation of microorganisms in foods: the past, the present and the future. Int. J. Food Microbiol., 117, 1-28.

Haas, G.J., Prescott, H.E., Dudly, E., Dick, R., Hintlian, C., and Keane, L. (1989) Inactivation of microorganisms by $\mathrm{CO}_{2}$ under pressure. J. Food Saf., 9, 253-65.

Hong, S.I., and Pyun, Y.R. (2001) Membrane damage and enzyme inactivation of Lactobacillus plantarum by high pressure $\mathrm{CO}_{2}$ treatment. Int. J. Food Microbiol., 63, 19-28.

Jeyamkondan, S., Jayas, D.S., and Holley, R.A. (1999) Pulsed electric field processing of foods. J. Food Prot., 62, 
1088-1096.

Klangpetch, W., Noma, S., Igura, N., and Shimoda, M. (2011) The effect of low-pressure carbonation on the heat inactivation of Escherichia coli. Biosci. Biotechnol. Biochem., 75, 1945-50.

Kohanski, M.A., Dwyer, D.J., Hayete, B., Lawrence, C.A., and Collins, J.J. (2007) A common mechanism of cellular death induced by bactericidal antibiotics. Cell, 130, 797-810.

Mosmann, T. (1983) Rapid colorimetric assay for cellular growth and survival: application to proliferation and cytotoxicity assays. J. Immunol. Methods, 65, 55-63.

Oulé, M.K., Kablan, T., Bernier, A.M., and Arul, J. (2006) Escherichia coli inactivation mechanism by pressurized $\mathrm{CO}_{2}$. Can. J. Microbiol., 52, 1208-1217.

Park, S.J., Lee, J.I., and Park, J. (2002) Effects of a combined process of high-pressure carbon dioxide and high hydrostatic pressure on the quality of carrot juice. J. Food Sci., 67, 1827-1834.

Parton, T., Toniolo, C., Elvassore, N., and Bertucco, A. (2003) Preservation of nutritive properties of tomato sauce by high pressure $\mathrm{CO}_{2}$ pasteurization. Proceedings of the 6th International Symposium on Supercritical Fluids. Versailles, France.

Shimoda, M., Cocunubo-Castellanos, J., Kago, H., Miyake,
M., Osajima, Y., and Hayakawa, I. (2001) The influence of dissolved $\mathrm{CO}_{2}$ concentration on the death kinetics of Saccharomyces cerevisiae. J. Appl. Microbiol., 91, 1-6.

Shimoda, M., Kago, H., Kojima, N., Miyake, M., Osajima, Y., and Hayakawa, I. (2002) Accelerated death kinetics of Aspergillus niger spores under high-pressure carbonation. Appl. Environ. Microbiol., 68, 4162-4167.

Spilimbergo, S., Bertucco, A., Basso, G., and Bertoloni, G. (2005) Determination of extracellular and intracellular $\mathrm{pH}$ of Bacillus subtilis suspension under $\mathrm{CO}_{2}$ treatment. Biotechnol. Bioeng., 92, 447-451.

Sun, C.A., Wang, L.Y., and Chen, C.J. (2001) Genetic polymorphisms of glutathione S transferases M1 and T1 associated with susceptibility to aflatoxin-related hepatocarcinogenesis among chronic hepatitis B carriers: a nested casecontrol study in Taiwan. Carcinogenesis, 22, 1289-1294.

Wei, Y.H., and Lee, H.S. (2002) Oxidative stress, mitochondrial DNA mutation, and impairment of antioxidant enzymes in aging. Exp. Biol. Med., 227, 671-682.

Wu, S.F., Beum, T.H., Yang, J.I., and Kim, J.N. (2007) Properties of Ca-Base $\mathrm{CO}_{2}$ sorbent using $\mathrm{Ca}(\mathrm{OH})_{2}$ as precursor. Ind. Eng. Chem. Res., 46, 7896.

Zhang, J., Davis, T.A., Matthews, M.A., Drews, M.J., LaBerge, M., and An, Y.H. (2006) Sterilization using highpressure carbon dioxide. J. Supercrit. Fluid, 38, 354-372. 